Proc. Estonian Acad. Sci. Geol., 2004, 53, 3, 165-189

\title{
Orogenic structures of the Precambrian basement of Estonia as revealed from the integrated modelling of the crust
}

\author{
Tarmo All ${ }^{\mathrm{a}, \mathrm{b}}$, Väino Puura, ${ }^{\mathrm{a}, \mathrm{c}}$, and Rein Vaher $^{\mathrm{c}}$ \\ a Institute of Geology, University of Tartu, Vanemuise 46, 51014 Tartu, Estonia; puura@ut.ee \\ b Geological Survey of Estonia, Kadaka tee 82, 12618 Tallinn, Estonia; t.all@egk.ee \\ ${ }^{c}$ Institute of Geology at Tallinn University of Technology, Estonia pst. 7, 10143 Tallinn, Estonia; \\ vaher@gi.ee
}

Received 14 August 2003, in revised form 7 November 2003

\begin{abstract}
Up-to-date gravity and magnetic field maps and deep seismic sounding data were used to study the orogenic structure of the Palaeoproterozoic (1.9-1.8 Ga) Svecofennian basement of Estonia. The structure of the crust was quantitatively modelled for two NNE-SSW trending profiles across the main - south (southwest) and north (northeast) - structural terrains and the tectonic transition zone between them. Lateral variability of the basement structure was revised using the available geological and geophysical maps and results of 3D modelling.

Metavolcanic and metasedimentary rocks prevail in the orogenic basement of the Estonian mainland. The crust is overthickened, thus a remarkable gravity minimum is expected to occur here. In NNE Estonia, where the low-density $\left(2680-2710 \mathrm{~kg} / \mathrm{m}^{3}\right)$ migmatized metamorphic rocks of the amphibolite facies prevail in the upper crust, the moderately overthickened $(45-50 \mathrm{~km})$ crust is coupled with gravity $(-10$ to $-40 \mathrm{mGal}$ ) and magnetic (down to $-800 \mathrm{nT}$ ) low. The deepest gravity minimum $(-40 \mathrm{mGal})$ is associated with the thick and light upper crust at the Tallinn zone. In SSW Estonia and northern Latvia, the extremely overthickened $(50-65 \mathrm{~km})$ crust is composed of the dense $\left(2750-2840 \mathrm{~kg} / \mathrm{m}^{3}\right)$ upper crust and overthickened, partially upthrusted lower crust. Here the mass deficit is compensated, and in many cases even overcompensated, by the upper crust composed of granulite facies rocks and blocks of the upthrusted lower crust. The Paldiski-Pskov zone is a transition between the two terrains, following deep crustal shear zones that dip to the SSW. The survived orogenic structure of the Estonian mainland formed due to the late Svecofennian SSW-NNE directed compression that resulted in crustal shortening and thickening, with the upthrusts along the Paldiski-Pskov zone and maximal crustal thickness in the SSW.
\end{abstract}

Key words: magnetic and gravity modelling, upper crust, lower crust, deep seismic sounding, Estonia. 


\section{INTRODUCTION}

Estonia is situated on the southern slope of the Fennoscandian Shield. Here, the crystalline basement is buried under the 100-800 m thick Upper Vendian and Palaeozoic cover. Due to the sedimentary cover, gravity and magnetic field interpretations, supported by geological and petrophysical studies of drill core samples (Puura et al. 1983; Puura 1997), play a central role in the investigations of the structure and evolution of the basement, and in geological mapping (Fig. 1; see also Soesoo et al. 2004) (Puura 1980; Koistinen 1994). The Sovetsk-KohtlaJärve deep seismic sounding (DSS) profile (Ankudinov et al. 1994) and correlations with the surrounding territories have provided new data on the deep structure (Puura et al. 1992; Koistinen 1994) and revealed a thick (up to $65 \mathrm{~km}$ ) crust in that region (Luosto 1991; Korja 1995). A regional, NW-SE striking PaldiskiPskov zone (PPZ) of deep-sitting faults bisects the basement of Estonia into two NNE and SSW - parts. Bearing in mind the regional level of gravity and magnetic field, Fotiadi (1958) initially named them the North Estonian Geophysical Low (NEGL) and Baltic-Belarus Geophysical High (BBGH), respectively. The

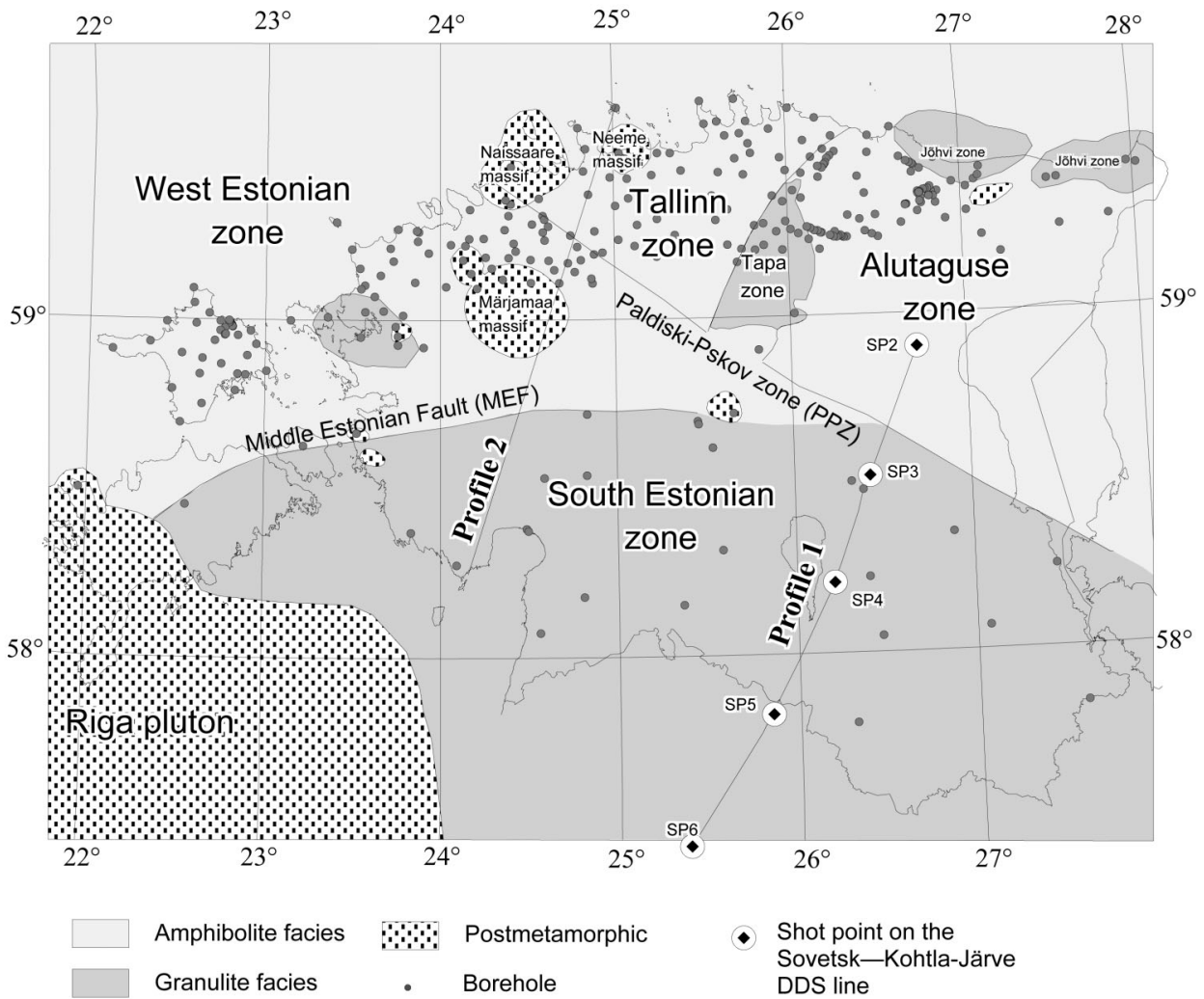

Fig. 1. The metamorphic and structural zonation of the Precambrian basement of Estonia. 
Paldiski-Pskov zone is an outstanding super-regional discontinuity within the Svecofennian Domain, well observable on geophysical maps and dividing the gravity and magnetic anomaly maps into two distinct anomaly patterns. On the DSS profile, a sharp gradient zone of Moho and Conrad discontinuity surfaces is located in the PPZ. On the basement surface map, the PPZ in its southeastern path divides the basement into areas of amphibolite and granulite facies of metamorphism, in the NNE and SSW, respectively. Another significant fault zone, the Middle Estonian Fault (MEF), starts from Saaremaa Island and trends eastward. It crosscuts the PPZ in Central Estonia and is well pronounced in West Estonia. To the east of the PPZ, the MEF is somewhat difficult to observe on the gravity and magnetic anomaly maps as well as on the basement relief map (Fig. 1, see also Soesoo et al. 2004).

In SSW Estonia, the maximal thickness of the crust appeared to be incompatible with the generally high level of the gravity field, especially in South Estonia, as designed on maps before the 1990s. Fortunately, this incompatibility was partly an artefact due to incorrect gravity systems used in former times. Using recalculated gravity field intensities and maps revised by H. Sildvee in 1995 (Sildvee 1997), a reasonable match between the deep seismic and gravity data was achieved (see below).

To interpret the Earth's crust structure of Estonia, we attempted to apply integrated quantitative gravity and magnetic modelling together with DSS data. In mainland Estonia, the influence of Wiborg and Riga rapakivi igneous centres on the orogenic structure and its geophysical reflections is minimal (Puura \& Flodén 1999, 2000). Two interpretation profiles across the main structural units of the basement were selected. The first profile traces the northern part of the Sovetsk-Kohtla-Järve DSS profile (Fig. 1). The second crosscuts the main fault zones in West Estonia. The main goal of modelling was to study the structures of the Earth's crust across the PPZ, particularly to compare the NNE and SSW terrains. We also made an attempt to evaluate, how the regional gravity field level is influenced by the deep sources such as the depth (relief) of Moho and Conrad discontinuities.

\section{MATERIALS AND METHODS}

Compared to previous interpretations, a new geophysical database and complex modelling methods are used in the present paper. In addition to the gravity and aeromagnetic maps at scales of 1:500 000-1:50 000 from the 1960s, the following works have been performed since 1976:

1. Detailed aeromagnetic mapping at a scale of $1: 25000$ on the mainland and 1:50 000 on the sea in 1987-1992 (Boiko 1991; Metlitskaya \& Popko 1992; Stepanov et al. 1992).

2. Detailed gravity mapping project of North Estonia (at a scale of 1:50 000) by the Geological Survey of Estonia (GSE) in 1968-1988. In 1992 a project including the revision, digitizing, and reinterpretation of the existing gravity data was initiated by the GSE (All et al. 1999, 2002). 
Three geophysical achievements favour links between geological and geophysical interpretations:

1. Gravity Anomaly Map of Estonia at a scale of 1:1000 000 in the IGSN 71 gravity system (Sildvee 1997). The Estonian regional gravity map based on 4195 on-land gravity stations was converted from the Potsdam gravity system into the IGSN 71 gravity system. The difference between those gravity systems determined for the Estonian area was $-15.4 \mathrm{mGal}$ (instead of the theoretical $-14 \mathrm{mGal}$ ). Gaps in the coverage by Maasik (1959) were patched by later seaborne and detailed on-land gravity measurements (Faitelson \& Aleksashin 1968; All et al. 1999, 2002). The value of the normal gravity field for the Estonian area according to the International Gravity Formula of 1980 differs by about $-6.5 \mathrm{mGal}$ from the values calculated by Cassini's 1930 Formula (used in Estonia before the 1960s) and by about $-2 \mathrm{mGal}$ from the values calculated by Helmert 1901-1909 Formula (used in Estonia from the 1960s to 1990s), on average (Margot 1997). Thus, compared to the earlier gravity maps, the regional level of the gravity field has been reduced significantly. The changes in the regional level of the gravity field do not affect detailed interpretations of local structures. However, it is important for the regional-scale crustal regionalization and modelling.

2. In 1997 Estonia joined the Finnish Crustal Model Program. In the frames of this project 13 geological, geodetic, and mapping institutions from Finland, Sweden, Norway, Russia, and Estonia collected numerical geological, geophysical, and petrophysical information at a scale of 1:1000 000 (Korhonen et al. 1999). An aeromagnetic anomaly map, based on various aeromagnetic mapping projects carried out by institutions of the former USSR (Fursov \& Ivanyukov 1960; Lapina \& Samoilyuk 1966; Boiko 1991; Stepanov et al. 1992; Metlitskaya \& Popko 1992), was composed. The data were reduced to the DGRF-65 anomaly level and the grid of $1 \mathrm{~km} \times 1 \mathrm{~km}$ was provided.

3. Luosto (1991) used DSS data available from the late 1980s and early 1990s to compile the Moho depth map of the Fennoscandian Shield. Korja (1995) modified the map (Fig. 2). The Estonian portion of the map is based on the data obtained from the Sovetsk-Kohtla-Järve DSS line (Fig. 3) by Ankudinov et al. (1994). Additionally, the data of the DSS line in the Baltic Sea (Ostrovski 1990), providing supplementary information about the Baltic Sea area, were taken into consideration.

The Bouguer anomaly maps in gravity and magnetic anomaly or total intensity maps in magnetic display best the complicated structure of the crystalline basement. The influence of the thickness and petrophysical variations of the sedimentary cover are irrelevant and can be excluded in crustal modelling. Calculating the 2nd vertical derivative, horizontal gradient or shaded relief maps can enhance the variety of potential field anomalies. These contribute to perceiving, locating, delineating, and classifying geological formations and structures affecting the fields. In Figs. 4-6, a selection of gravity and magnetic anomaly maps for the Estonian territory is presented. 


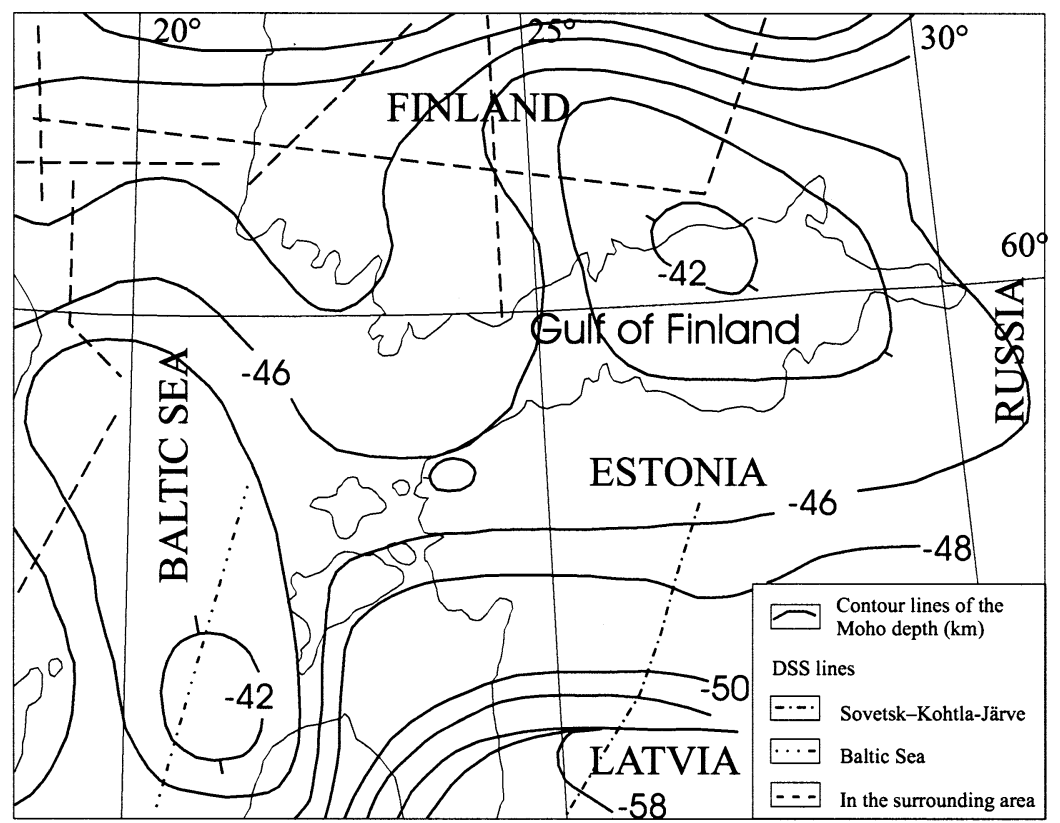

Fig. 2. Two-dimensional crustal cross-section along the northeastern part of the Sovetsk-KohtlaJärve deep seismic sounding profile (modified from Ankudinov et al. 1994).

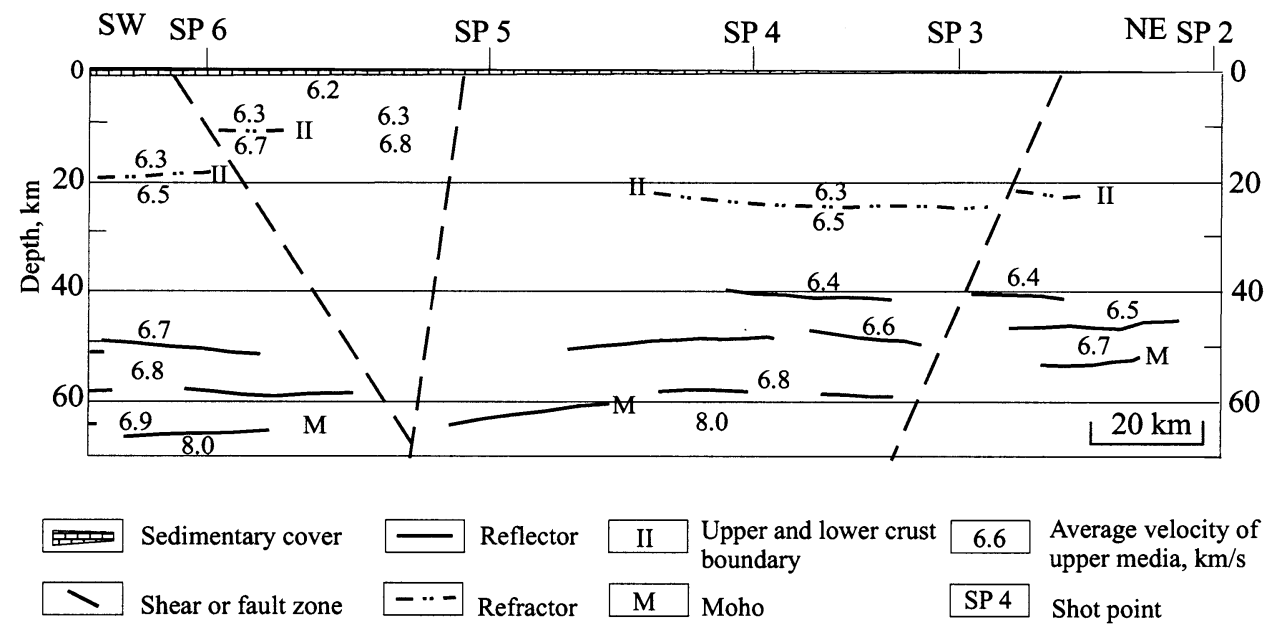

Fig. 3. The Moho depth in the Fennoscandian Shield (modified from Korja 1995). 
(a)

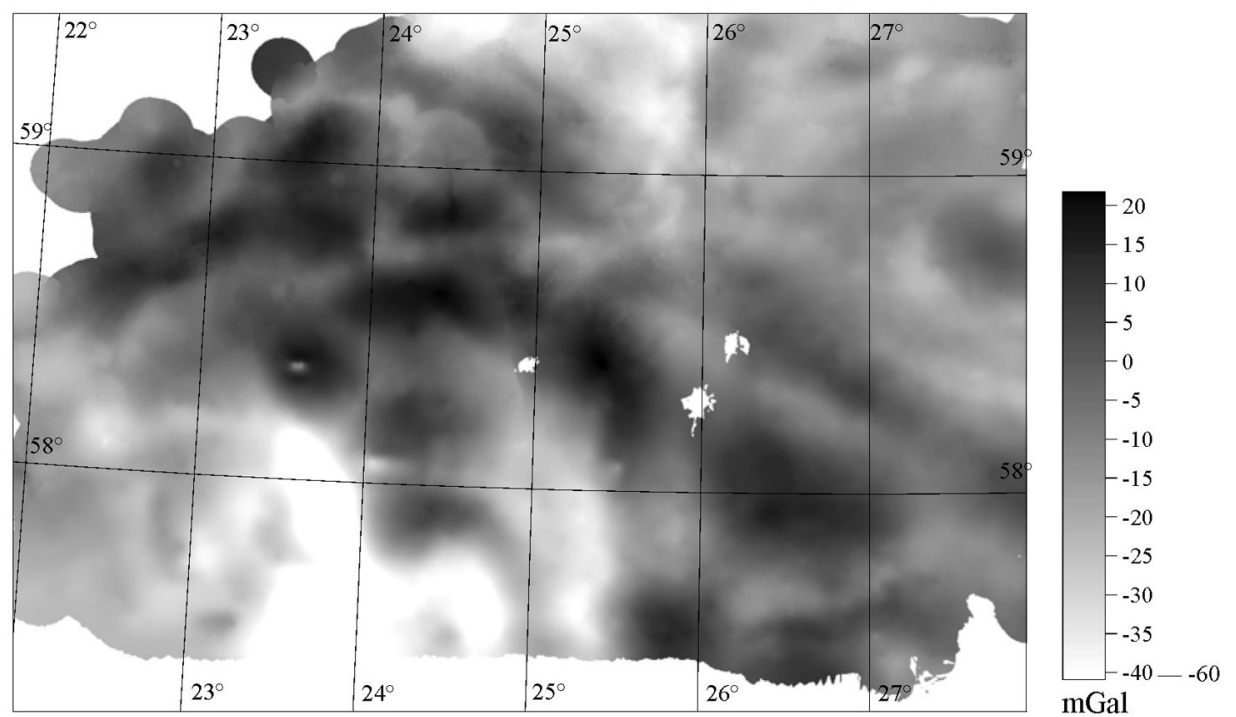

(b)
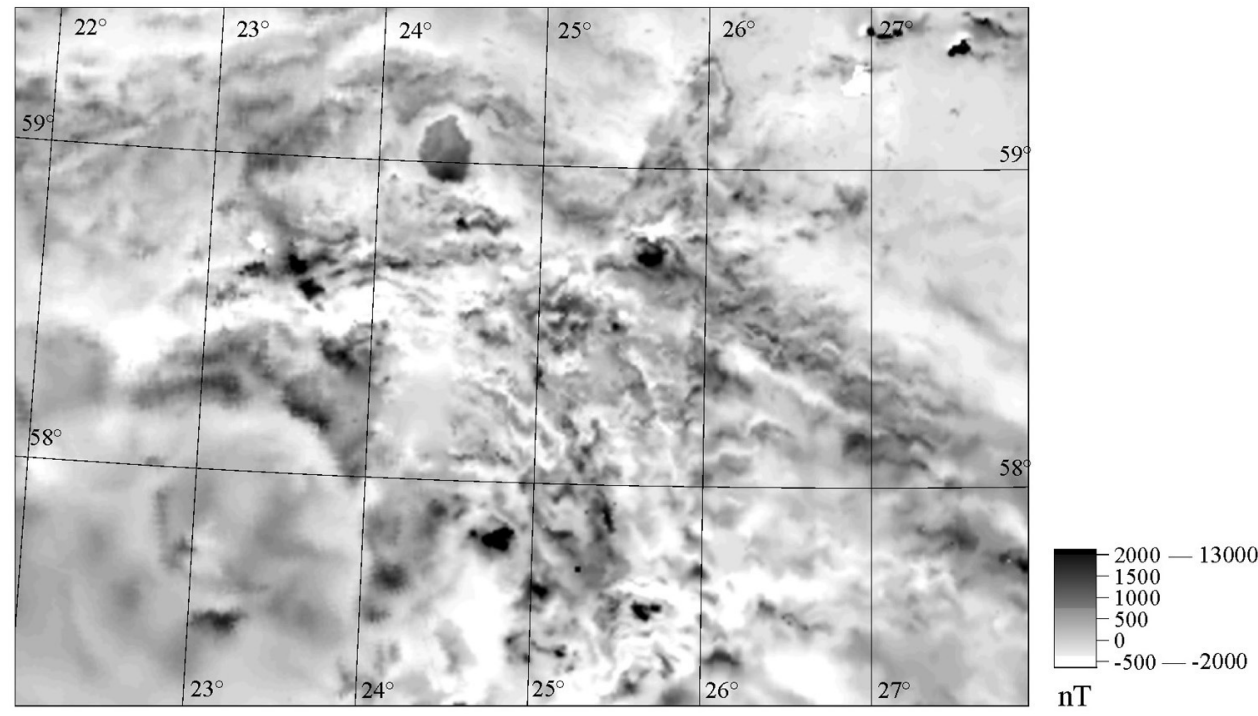

Fig. 4. The Bouguer (a) (density $2670 \mathrm{~kg} / \mathrm{m}^{3}$, IGSN 71 system, International Gravity Formula) and aeromagnetic (b) DGRF-65 anomaly maps of Estonia. The gravity map is produced from the original gravity data of the Institute of Geology at Tallinn University of Technology (Maasik 1959). Measurements by Voldemar Maasik, digitizing by Heldur Sildvee. The aeromagnetic map was compiled by the Institute of Geology at Tallinn University of Technology, and the Geological Survey of Finland based on the data of the Geological Survey of Estonia. 
(a)

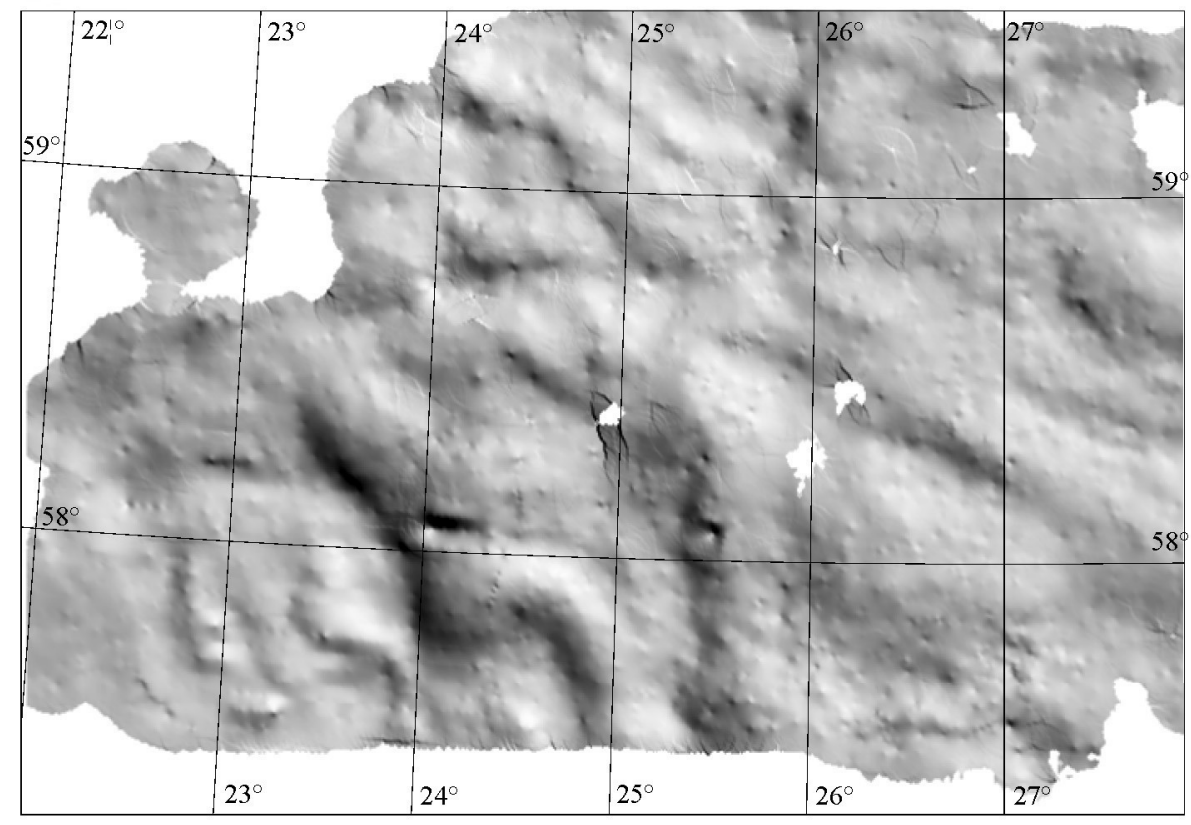

(b)

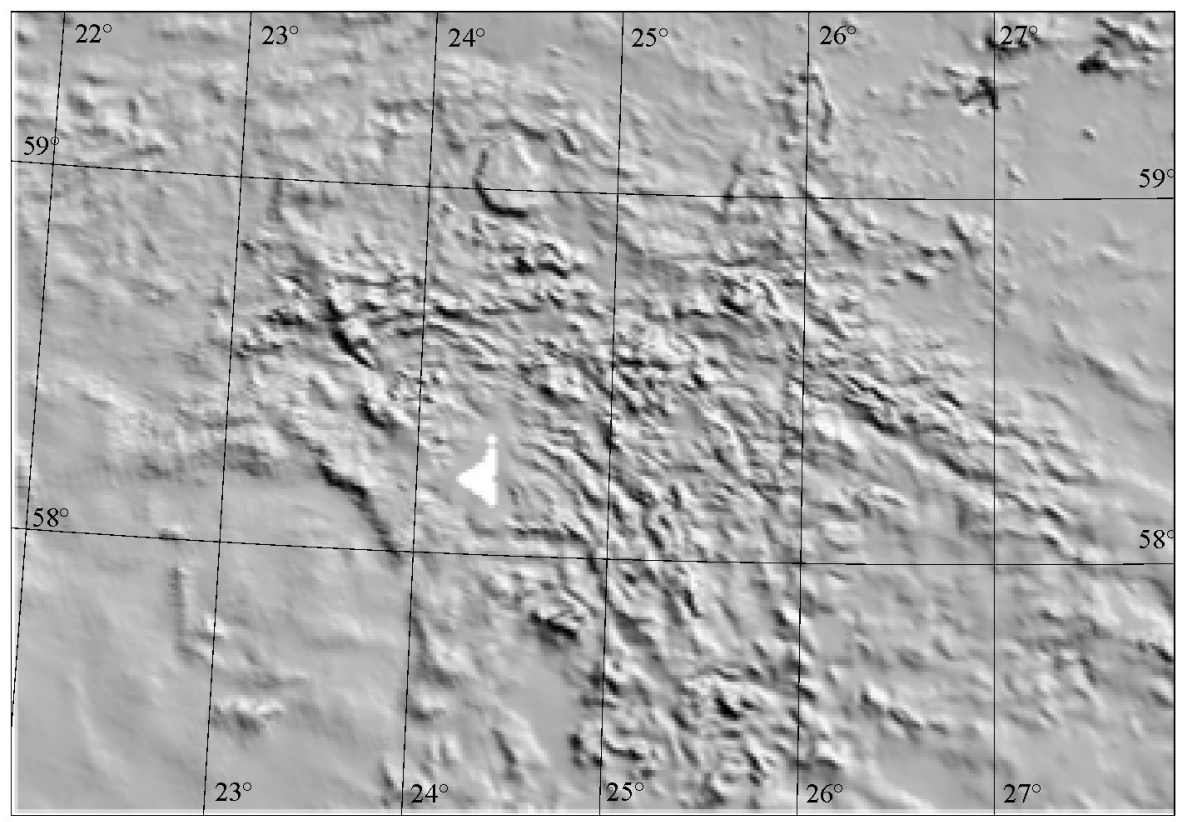

Fig. 5. The shaded relief of the Bouguer (a) and aeromagnetic (b) anomaly maps of Estonia. Lighting from NE. 


\section{(a)}

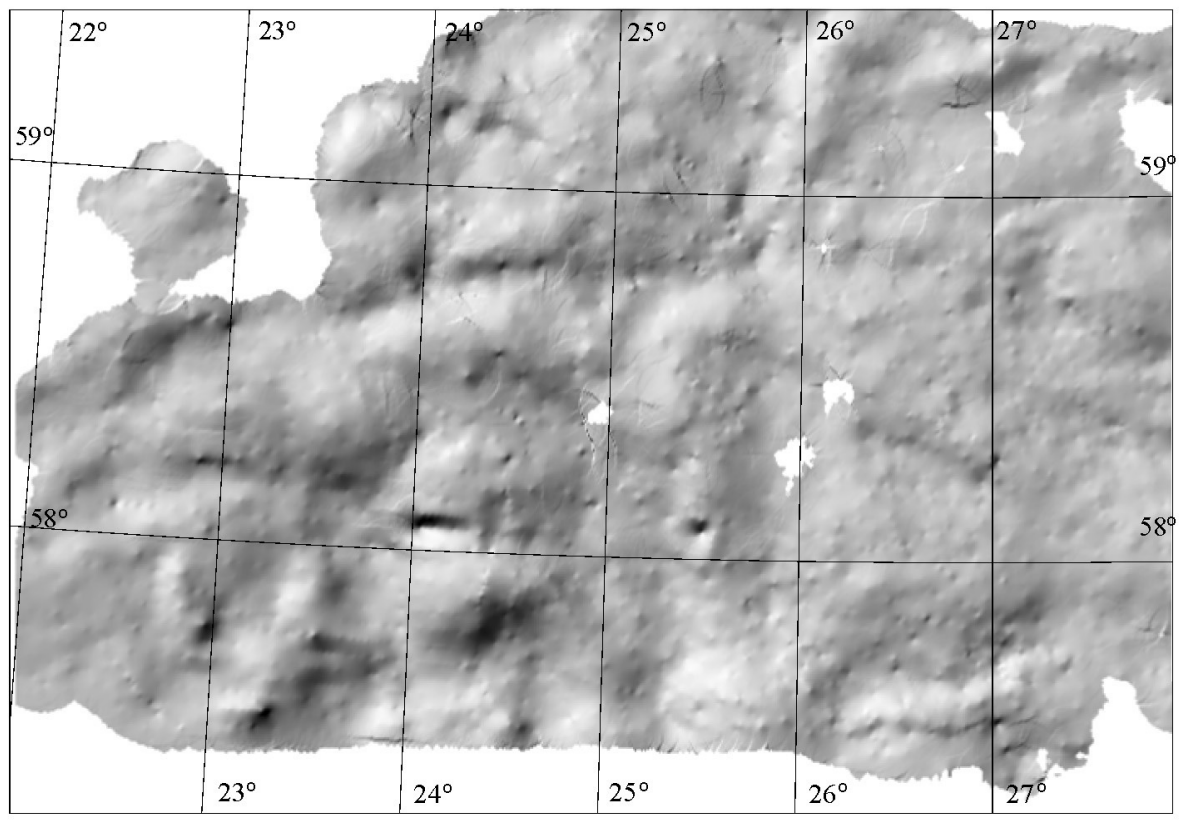

(b)

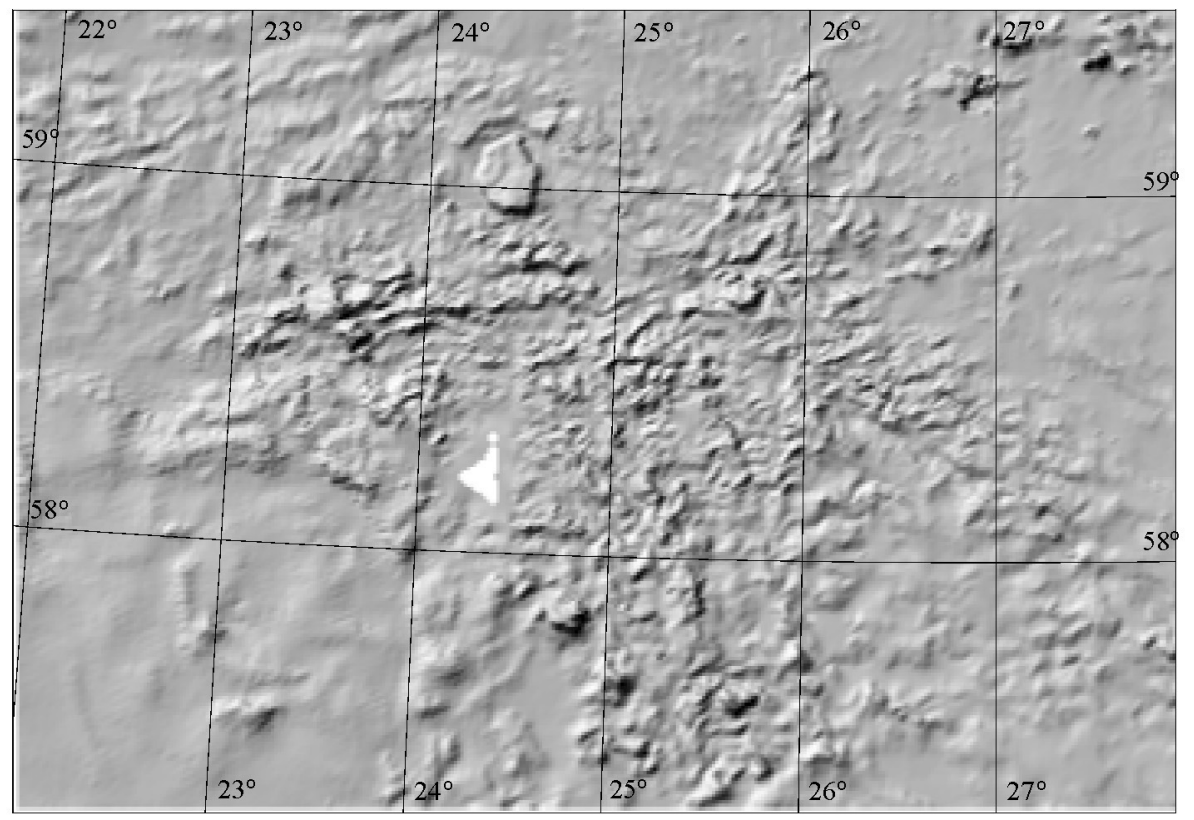

Fig. 6. The shaded relief of the Bouguer (a) and aeromagnetic (b) anomaly maps of Estonia. Lighting from NW. 
Geology of the basement of Estonia is patchily studied. A total of 437 boreholes have been drilled into the crystalline basement in North Estonia (West Estonian zone, Tallinn zone, Tapa zone, Jõhvi zone and most of the Alutaguse zone; see Fig. 1), from which about $31 \mathrm{~km}$ of core has been extracted (Koppelmaa \& Kivisilla 2000). However, only 50 drill cores are available for Central and South Estonia (southernmost part of the Alutaguse zone and the South Estonian zone). Nowadays, the petrophysical database on the Estonian basement contains about 8300 samples, not including 1100 weathered samples. Also, new petrophysical information on crystalline rocks of Finland (Pesonen et al. 1989; Puranen 1989; Lahtinen \& Korhonen 1996; Korhonen et al. 1997) is useful for the studies of the basement in Estonia and under the Baltic Sea.

In the neighbouring areas, e.g. in the Fennoscandian Shield, combined 2.5D and 3D gravity and magnetic modelling along DSS lines has been successfully used for the interpretation of the crustal and upper mantle structure since the late 1980s (Elo et al. 1989; Henkel et al. 1990; Marker et al. 1990; Elo \& Korja 1993). In Estonia, only qualitative or semiquantitative comparisons of potential fields and petrophysical data (e.g. Puura et al. 1983) were performed until the 1990s. Two-dimensional gravity and magnetic modelling of the uppermost crust (to a depth of 6-9 km) was used to study local structures. Since 1996, attempts have been made to model local basement structures of Estonia (All \& Puura 1998; Suuroja et al. 2002). The results obtained in the framework of the joint Finnish Crustal Model Program are included in the present paper.

\section{QUANTITATIVE MODELLING}

Regional gravity and aeromagnetic datasets were used as the main data sources for modelling (Fig. 4). The petrophysical database comprises the mean densities and magnetic susceptibilities of more than 9000 core samples (mainly published by Puura et al. 1983). Mean values for prevailing rock types of the distinguished structural zones (Fig. 1; Table 1) were taken into consideration when calculating properties of the uppermost crust. Data on palaeomagnetic inclination and declination of the Fennoscandian Shield were obtained from Pesonen et al. (1989).

Three-dimensional models consist of a number of blocks with a polygonal cross-section. Their density and susceptibility values differ as indicated in Figs. 7 and 8 . The advantage of the combined modelling over the gravity modelling alone is that the magnetic modelling has the unique ability to resolve dips of geological interfaces, which can be used to constrain shapes of gravity bodies applied in the modelling of the structure.

The modelling concentrated on the block and fault structure of the upper crust and the thickness variations of the lower crust. The interpretation represents a two-layer crust underlain by a lower crustal Moho transition zone with P-wave velocities greater than $8 \mathrm{~km} / \mathrm{s}$. The background gravity field for the modelling was defined as zero and the observed gravity field was interpreted against a reference 
Table 1. Petrophysical properties of rapakivi granites and the most common rock types from main orogenic structural zones

\begin{tabular}{|c|c|c|c|c|c|c|c|c|c|c|}
\hline \multirow{2}{*}{ Rock type } & \multicolumn{4}{|c|}{ Density, $\mathrm{kg} / \mathrm{m}^{3}$} & \multicolumn{4}{|c|}{ Susceptibility, $10^{-6} \mathrm{SI}$} & \multicolumn{2}{|c|}{$Q$-ratio } \\
\hline & $N$ & Min & $\operatorname{Max}$ & Mean & $N$ & Min & Max & Mean & $N$ & Mean \\
\hline \multicolumn{11}{|l|}{ Rapakivi massifs } \\
\hline Märjamaa II phase & 55 & 2593 & 2746 & 2663 & 55 & 150 & 20470 & 2648 & 55 & 0.83 \\
\hline Neeme I phase & 65 & 2620 & 2730 & 2654 & 65 & 276 & 10220 & 3014 & 65 & 0.22 \\
\hline Neeme II phase & 14 & 2614 & 2650 & 2631 & 14 & 90 & 420 & 188 & 14 & 3.32 \\
\hline \multicolumn{11}{|c|}{ Orogenic structural zones } \\
\hline \multicolumn{11}{|l|}{ Alutaguse zone } \\
\hline $\begin{array}{l}\text { Gneisses, } \\
\text { migmatized }\end{array}$ & 360 & 2540 & 2890 & 2680 & 282 & 10 & 2010 & 138 & & \\
\hline \multicolumn{11}{|l|}{ Tallinn zone } \\
\hline $\begin{array}{l}\text { Metamorphic rocks, } \\
\text { migmatized }\end{array}$ & 1158 & 2530 & 3310 & 2700 & 3801 & 10 & 471000 & 289 & 331 & 3.4 \\
\hline $\begin{array}{l}\text { Quartz-feldspar } \\
\text { gneisses }\end{array}$ & 138 & 2540 & 2750 & 2620 & 484 & 10 & 23490 & 151 & 46 & 0.71 \\
\hline $\begin{array}{l}\text { Amphibole gneisses, } \\
\text { amphibolites }\end{array}$ & 367 & 2570 & 3090 & 2770 & 1374 & 10 & 30270 & 528 & 159 & 2.3 \\
\hline Al-rich gneisses & 366 & 2530 & 3310 & 2710 & 1305 & 10 & 361700 & 377 & 95 & 7.1 \\
\hline \multicolumn{11}{|l|}{ West Estonian zone } \\
\hline $\begin{array}{l}\text { Amphibole gneisses, } \\
\text { amphibolites }\end{array}$ & 145 & 2620 & 3140 & 2800 & 145 & 100 & 77870 & 2470 & 98 & 1.1 \\
\hline $\begin{array}{l}\text { Metamorphic rocks, } \\
\text { migmatized }\end{array}$ & 365 & 2540 & 3110 & 2760 & 804 & 10 & 111500 & 3790 & 170 & 1.13 \\
\hline \multicolumn{11}{|l|}{ South Estonian zone } \\
\hline $\begin{array}{l}\text { Metamorphic rocks, } \\
\text { migmatized }\end{array}$ & 442 & 2590 & 3360 & 2780 & 354 & 25 & 283900 & 9040 & 282 & 1.01 \\
\hline $\begin{array}{l}\text { Amphibole- } \\
\text { pyroxene gneisses }\end{array}$ & 171 & 2620 & 3360 & 2840 & 172 & 50 & 283900 & 21250 & 159 & 1.08 \\
\hline Al-rich gneisses & 116 & 2670 & 3060 & 2830 & 53 & 126 & 116200 & 2460 & 19 & 1.08 \\
\hline
\end{tabular}

model (i.e. one giving the Bouguer anomaly of zero) comprising an upper crust of density $2710 \mathrm{~kg} / \mathrm{m}^{3}$ to a depth of $20 \mathrm{~km}$, a lower crust of density $2950 \mathrm{~kg} / \mathrm{m}^{3}$ from 20 to $40 \mathrm{~km}$, and an upper mantle of density $3200 \mathrm{~kg} / \mathrm{m}^{3}$. The background magnetic field was also set to zero (i.e. equal to the reference field that had previously been removed from the data).

The DSS data were used as a starting point for the modelling. Introducing the reliefs of the Moho and Conrad discontinuities refined the initial model. This model was then used as a broad-scale background structure for modelling the 


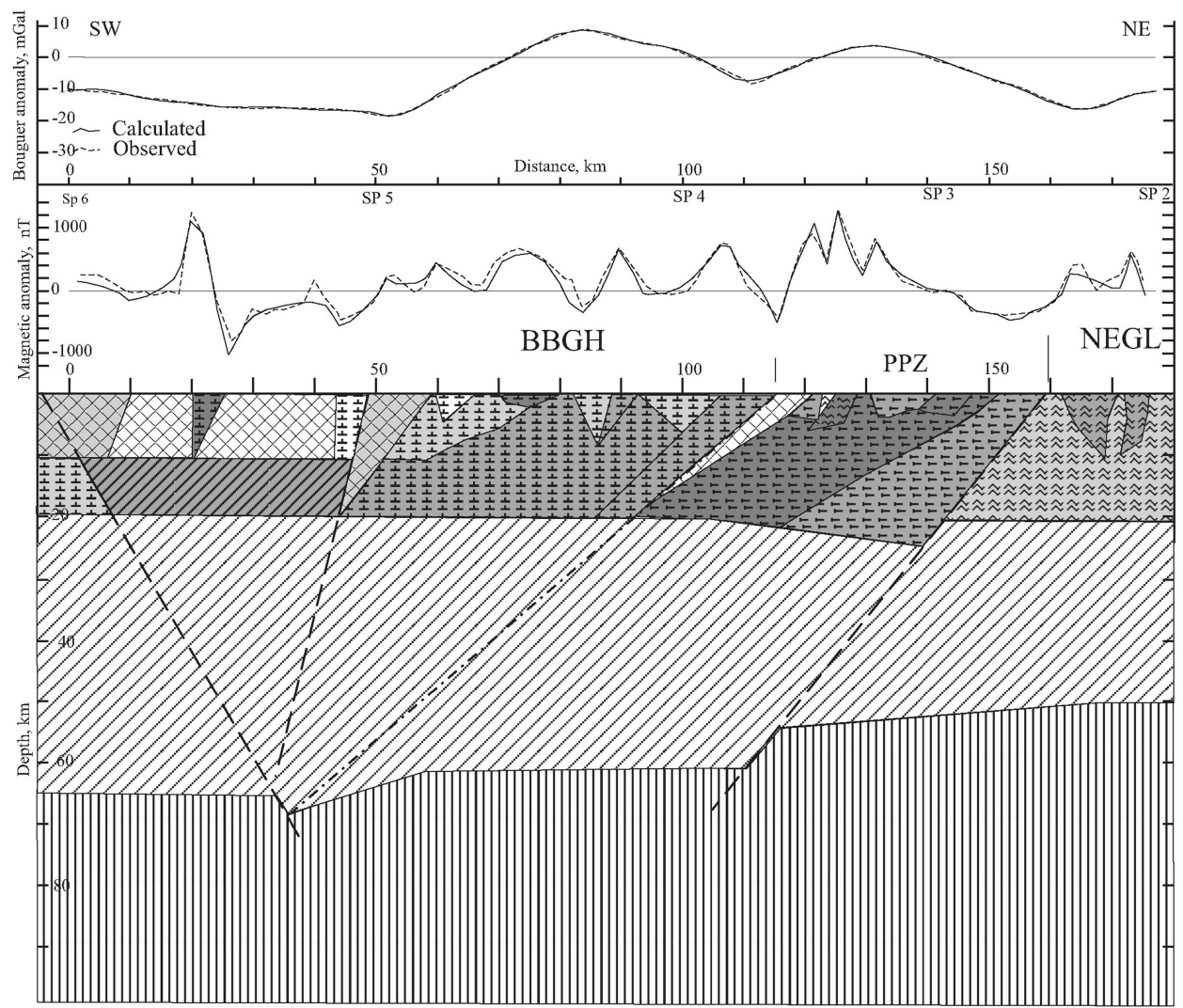

\begin{tabular}{|c|c|c|c|}
\hline$\approx \approx \approx \approx \lambda$ & $\begin{array}{l}\text { Mica schist and mica gneiss } \\
\text { (Alutaguse zone, } D=2680-2700 \mathrm{~kg} / \mathrm{m}^{3} \text { ) }\end{array}$ & $E E=$ & $\begin{array}{l}\text { Mafic and intermediate metavolcanic rocks (South Estonian } \\
\text { zone in the Paldiski-Pskov zone, } D=2770-2790 \mathrm{~kg} / \mathrm{m}^{3} \text { ) }\end{array}$ \\
\hline 토포포 & $\begin{array}{l}\text { Mafic and intermediate metavolcanic rocks } \\
\text { (South Estonian zone, } D=2790-2820 \mathrm{~kg} / \mathrm{m}^{3} \text { ) }\end{array}$ & $\notin X$ & $\begin{array}{l}\text { Granite and granite gneiss } \\
\left(\mathrm{D}=2680-2720 \mathrm{~kg} / \mathrm{m}^{3}\right)\end{array}$ \\
\hline $\mathrm{ECC}$ & $\begin{array}{l}\text { Lower crust } \\
\left(\mathrm{D}=2950 \mathrm{~kg} / \mathrm{m}^{3}\right)\end{array}$ & 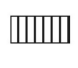 & $\begin{array}{l}\text { Mantle } \\
\left(\mathrm{D}=3200 \mathrm{~kg} / \mathrm{m}^{3}\right)\end{array}$ \\
\hline-7 & $\begin{array}{l}\text { Ductile shear or thrust zone } \\
\text { (after Koistinen 1994) }\end{array}$ & 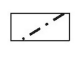 & $\begin{array}{l}\text { Ductile shear or thrust zone } \\
\text { (interpreted from potential fields) }\end{array}$ \\
\hline
\end{tabular}

Fig. 7. Profile 1: magnetic and gravity profiles across the Paldiski-Pskov zone (PPZ). For location see Fig. 1. Solid and dashed lines denote observed and calculated values, respectively. The calculated gravity and magnetic curves correspond to the presented geological-geophysical model. 


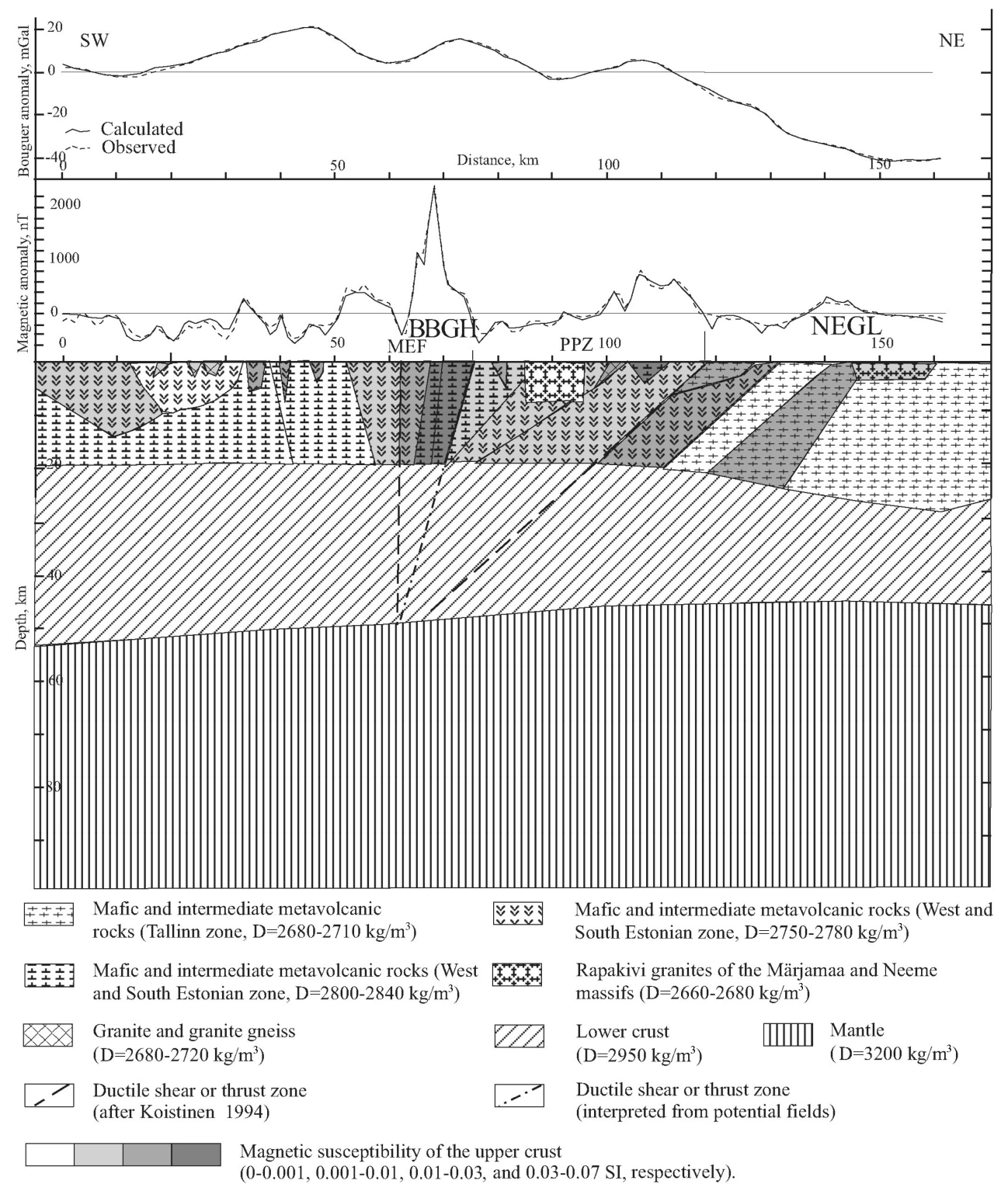

Fig. 8. Profile 2: magnetic and gravity profiles across the Paldiski-Pskov zone (PPZ) and Middle Estonian Fault (MEF). For location see Fig. 1. Solid and dashed lines denote observed and calculated values, respectively. The calculated gravity and magnetic curves correspond to the presented geological-geophysical model. 
upper crustal bodies responsible for the shorter wavelength gravity and magnetic anomalies. Individual bodies were defined with either density or magnetization contrast or both with respect to the upper crustal layers. They are described with bodies of polygonal cross-section, striking perpendicular to the profile with $50 \mathrm{~km}$ extension in the strike direction. In cases of small units, as the rapakivi intrusions and postorogenic granitoids the spatial configuration was taken from the Map of the Precambrian Basement (Koistinen 1994). The interactive adjusting of either the body shape or its properties until a good fit to both the gravity and magnetic fields was obtained progressively refined the interpretation.

In determining the existence of upthrust zones in the PPZ, our modelling encountered some difficulties and uncertainties. Namely, the measured values of physical properties of rocks reflect only properties of the topmost layer of the basement and cannot be a priori generalized for the basement blocks. Due to unoriented drill core samples, directions of remanent magnetization remain unknown. At the same time, remanence plays an essential role in the pyrrhotitebearing rocks of the amphibolite facies terrain (NEGL) (Puura et al. 1983). The Königsberger ratio $(Q)$ varies from 1 to 10 there. Otherwise, it is commonly less than 1 for granulites in South Estonia. Using wrong values for $Q$ may produce significant errors, especially in the NE end of the magnetic profiles. Therefore, by the interpretation of modelling results, we had to assign greater importance to the density data.

\section{Profile 1}

Profile 1 running along the DSS profile (Fig. 7) starts within the BBGH in South Estonia, in the granulite facies domain (Fig. 1). It crosscuts the PPZ and extends into the NEGL, the amphibolite facies terrain. The Conrad and Moho discontinuity reliefs were taken from seismic interpretations (Ankudinov et al. 1994; Sildvee \& Vaher 1995). The overthickened crust $(50-65 \mathrm{~km})$ reduces the calculated gravity level considerably, as a mass deficit of at least $100-200 \mathrm{~kg} / \mathrm{m}^{3}$ should exist under the level of 40-45 km. According to the seismic data, the lower crust is uplifted for about $9-10 \mathrm{~km}$ between shot points 5 and 6 (Figs. 3 and 7). A mass contrast of about $+200 \mathrm{~kg} / \mathrm{m}^{3}$ can be expected here, which compensates the negative effect of the thick crust (more than $60 \mathrm{~km}$ ) to some extent. The postorogenic granites and granite gneisses, mainly forming the crust above and around the upthrust blocks, are of nearly upper crust density, thus having only a minor influence on the gravity level.

Two distinct positive Bouguer anomalies in the middle part of the profile (Fig. 7) manifest the BBGH. The DSS data, and the gravity and magnetic anomaly pattern (Figs. 3-6) suggest that the basement block consisting mainly of highly metamorphosed and high-density $\left(2770-2820 \mathrm{~kg} / \mathrm{m}^{3}\right)$ rocks is delimited by deep faults in the SW and NE. On the 120th km of the profile, a deep-seated fault is interpreted from the potential anomaly pattern (Figs. 4-6). It represents the SW limit of the PPZ. The dominant southwestward dip of the boundaries of basement 
blocks was obtained by magnetic modelling and supported by a seismic model (Fig. 3). The low-density granite body shown on geological maps has an about $45^{\circ}$ dip to the SSW. The large amount of high-density mass in the upper crust as a mass excess and the mass deficiency in the lowermost part of the lower crust counterbalance each other's gravity effects, therefore together preserving the isostatic equilibrium.

On the NE end of the profile, the low-density upper crust consisting of mica schist and mica gneisses, juxtaposed to the thick $(\sim 30 \mathrm{~km})$ lower crust, produces a great mass deficiency. A low (down to $-17 \mathrm{mGal}$ ) gravity field manifests the NEGL.

\section{Profile 2}

Profile 2 (Fig. 8) starts from South Estonia, crosscuts the western rim of the Märjamaa rapakivi massif, extends to the North Estonian amphibolite facies terrain, and ends on the Neeme rapakivi intrusion (Fig. 1). It crosses both the MEF and PPZ. Notable changes in the Bouguer anomaly level can be followed on the profile. Positive Bouguer anomalies with amplitudes up to $+18 \mathrm{mGal}$ occur in the SW and central part, a deep negative one with the amplitude down to $-40 \mathrm{mGal}$ is observed in the NE part. Based on the magnetic and gravity curves, the following dissimilar segments ( $a, b$, and c) can be differentiated from SW to NE:

(a) In the southwesternmost part of the profile (BBGH, South Estonian granulite area), within $0-20 \mathrm{~km}$ a slightly variable low magnetic field dominates (Fig. 8). The gravity field remains at about zero level. Here the negative effect of the slightly overthickened $(50-53 \mathrm{~km})$ crust is counterbalanced by a slightly denser $\left(2680-2750 \mathrm{~kg} / \mathrm{m}^{3}\right)$ than regular $\left(2690-2710 \mathrm{~kg} / \mathrm{m}^{3}\right)$ Svecofennian crust. Further to the NE (within 20-55 km), high-density rocks $\left(2750-2840 \mathrm{~kg} / \mathrm{m}^{3}\right)$ form the upper crust and thus the positive gravity anomaly (up to $+18 \mathrm{mGal}$ ) occurs here.

The segments (a) and (b) are separated by the MEF, correlating with a linear negative magnetic anomaly belt ( -200 to $-500 \mathrm{nT}$, Fig. 4b) and a relative gravity low ( -5 to $+5 \mathrm{mGal}$, Fig. 4 a) against the mostly positive reference field.

(b) A variable magnetic curve, mainly positive in its central part $(55-120 \mathrm{~km}$ in Fig. 8) corresponds to the West Estonian zone and PPZ, constituting together the BBGH. The gravity and magnetic minima in the central part of this section are mostly caused by the marginal part of the Märjamaa rapakivi pluton (see fig. 1 in Soesoo et al. 2004). The influence of the Märjamaa rapakivi intrusion is obvious on both gravity and magnetic anomaly maps (Fig. 4). A block of low density $\left(2670 \mathrm{~kg} / \mathrm{m}^{3}\right)$ and susceptibility $\left(1000 \times 10^{-6} \mathrm{SI}\right)$ simulates its influence on the model. However, a potential field pattern (Figs. 4-6) indicates that a fault zone delimiting the PPZ in the SW occurs here as well. Considering the results of our modelling, the MEF is nearly vertical, whereas the faults manifesting the limits of the PPZ are tilted 
to the SW. The high-density rocks of the South Estonian granulite area $\left(2750-2840 \mathrm{~kg} / \mathrm{m}^{3}\right)$ are less dense $\left(2750-2780 \mathrm{~kg} / \mathrm{m}^{3}\right)$ but more magnetic in the frames of the PPZ. The blocks of the basement and inter-block faults are tilted southwestward within the PPZ and eastern part of the BBGH. However, further to the SW, the direction of the tilt changes and in the SW part the faults are tilted to the northeast (Figs. 7 and 8).

The contact of (b) and (c) is marked by a step in the magnetic field level (Figs. $4 \mathrm{~b}$ and $5 \mathrm{~b}$ ) and with a gradient zone in the gravity field (Figs. $4 \mathrm{a}$ and 5a). Both are associated to the deep-seated fault - the NE boundary of the BBGH (PPZ).

(c) A low and uniform field in the NE part of the profile $(120-160 \mathrm{~km}$ in Fig. 8) corresponds to the amphibolite facies (Tallinn zone) area of the NEGL. The negative gravity anomaly down to $-40 \mathrm{mGal}$ occurring here can be explained by the mass deficit produced mainly by the light (2680 $\left.2710 \mathrm{~kg} / \mathrm{m}^{3}\right)$ and thick $(25-29 \mathrm{~km})$ upper crust. The Neeme intrusion, in the northeasternmost end of the profile, is also of low density $\left(2660-2680 \mathrm{~kg} / \mathrm{m}^{3}\right.$, Table 1), but because of a restricted vertical extent (All \& Puura 1998) has only minor influence on the gravity field level.

\section{MAIN OROGENIC STRUCTURES OF THE BASEMENT}

Results of quantitative interpretations along the profiles, together with the mapping of the basement surface, enable a modernized insight into the lateral variability of the basement in the Estonian mainland. Here, in an area of some $40000 \mathrm{~km}^{2}$, orogenic metamorphic and igneous rocks dominate in the architecture of the basement. Specific geophysical signatures characteristic of the Svecofennian orogenic domain elsewhere dominate here. Aside from the Estonian mainland, the Wiborg (to the NE) and Riga (to the SW) rapakivi igneous centres spread over large areas (25000 and $41000 \mathrm{~km}^{2}$, respectively) (see Soesoo et al. 2004), surface and deep crustal structure and related geophysical signatures of the orogenic origin are lost and replaced by igneous patterns (Elo \& Korja 1993; Puura \& Flodén 1999). Post- and anorogenic (in the sense traditionally used in the Fennoscandian literature) massifs and faults within the orogenic structures in Estonia cause distinct minor anomaly signatures (Puura et al. 1983; All \& Puura 1998).

The whole territory of Estonia lies in the interior of the Palaeoproterozoic juvenile Svecofennian Crustal Domain (Puura \& Huhma 1993; Gorbatschev \& Bogdanova 1993). Its structural patterns have been studied in detail in the Fennoscandian Shield. Within Estonia, the folded basement is divided into a number of structural zones (Fig. 1; Puura et al. 1983; Koistinen et al. 1996). However, two main terrains of the basement differ largely in both geological and geophysical aspects. Most extensive faults or shear zones occurring as specific anomaly zones in geophysical fields mark the boundaries of the main structural units. 


\section{North-northeastern Estonia}

Low and relatively uniform gravity and magnetic fields corresponding to the NEGL characterize the amphibolite facies terrain in northern and NE Estonia (Fig. 4). Considerably regular east-southeast trending linear magnetic anomalies of low to medium intensity reflect parts of two folded belts - Tallinn and Alutaguse zones. The Tallinn zone is characterized by extremely low gravity ( -26 to $-40 \mathrm{mGal})$ and low magnetic $(-100$ to $-500 \mathrm{nT})$ anomalies, the Alutaguse zone by low gravity (on average $-20 \mathrm{mGal}$ ) and low magnetic (on average $-300 \mathrm{nT}$ ) anomalies. The Paide-Tapa transform fault zone and Tapa block of granulite facies rocks, producing a relative maximum of 10-15 mGal coupled with the positive magnetic anomalies (up to $500 \mathrm{nT}$ ), separate the Tallinn and Alutaguse zones. The gravity field in the Alutaguse zone is complicated by several relative highs, produced by blocks of high-grade metamorphic rocks (Jõhvi zone, Uljaste anomaly). The magnetite quartzites, discovered in the Jõhvi zone, are manifested by the sharpest magnetic anomaly of more than $13000 \mathrm{nT}$ (Fig. 4). Yet, in spite of extremely high density $\left(3470 \mathrm{~kg} / \mathrm{m}^{3}\right.$ on average; Puura et al. 1983), the quartzites do not produce any significant gravity anomaly, and their volume should thus remain insignificant. Local negative magnetic and gravity anomalies of low intensity reflect localities of intense late orogenic granite migmatization and/or intrusion.

The Tallinn zone of the North Estonian basement (see Soesoo et al. 2004, fig. 1) consists of prevailingly folded volcanic rocks of presumably volcanic arc origin. Its continuation might be observed in southern Finland (Puura et al. 1983; Koistinen 1994; Koistinen et al. 1996). The Alutaguse zone in NE Estonia is probably a part of a large, presently strongly folded sedimentary basin exceeding the St. Petersburg and Novgorod areas in Russia. The generally ENE orientation is probably due to the regional, SSW to NNE oriented late orogenic compression. A strike-slip deformation zone existing already prior to the late orogenic compression probably causes the Tapa block and NE-striking Paide-Tapa fault zone. Those structures separate the sedimentary-volcanic Tallinn and mainly sedimentary Alutaguse metamorphic zones. In the field of the high-grade amphibolite facies, local domes of the granulite facies occur also at Uljaste and Jõhvi (Puura et al. 1983). Local gravity and magnetic anomaly fields suggest a notably less complex internal structure of the upper crust than in SSW Estonia.

In the NNE, on both interpretation profiles the crust in total is thinner than the respective crustal units in SSW Estonia. On the NNE end of profile 2 (Fig. 8; Tallinn zone) the upper crust is thicker than elsewhere on the Estonian mainland. The pressure estimates of the metamorphism at the surface of the basement are around 3-5 kbar and less (Puura et al. 1983), suggesting a much smaller depth of erosion than in the SSW. In the case of the present crustal thickness of around $45 \mathrm{~km}$ and the eroded portion of the mountain chains of $10-15 \mathrm{~km}$, the initial total thickness of the Svecofennian orogen here could reach some $55-60 \mathrm{~km}$. The internal structure of the basement is very similar to the basement in southern and 
southeastern Finland (Koistinen et al. 1996), representing folded belts formed from volcanic arc and inter-arc lithologies. Crustal thickening and stacking, if present, occurred in considerably lesser intensity than in SSW of Estonia.

The gravity low associated with the Alutaguse zone is caused by a slightly lighter than average Svecofennian crust and overthickened $(45-50 \mathrm{~km})$ crust. In the Tallinn zone a deep gravity low is produced by a thick $(21-29 \mathrm{~km})$ and light $\left(2680 \mathrm{~kg} / \mathrm{m}^{3}\right)$ upper crust.

\section{South-southwestern Estonia}

A large area of prevailing mafic to intermediate granulites occurs in southern and southwestern Estonia. The assemblage of belt-form tectonic blocks and sheets of the granulite and amphibolite facies consists mainly of igneous - mafic, intermediate, and felsic volcanic and intrusive protoliths (Puura 1980; Puura et al. 1983; Koistinen et al. 1996). The temperature and pressure of the granulite metamorphism estimated for South Estonia are $700-800^{\circ} \mathrm{C}$ and 5-6 kbar (Koistinen et al. 1996). The regional granulite metamorphism, coupled with high rock density and magnetization, conceals the geological and potential field patterns characteristic of the proper Svecofennian in the Baltic Shield and North Estonia.

The granulite terrain of South Estonia and predominantly amphibolite terrain with occasional granulite spots of West Estonia are associated with similar patterns of potential fields, characterized by mostly positive Bouguer anomaly values (Figs. 4a, 5a, and 6a) and by very variable, mostly positive (up to $3000 \mathrm{nT}$ ) magnetic anomalies (Figs. 4b, 5b, and 6b). Besides the dominating WNW-ESE trend of linear anomalies, $\mathrm{N}-\mathrm{S}$ to $\mathrm{E}-\mathrm{W}$ trending anomaly belts occur in many localities. As expressed in potential fields, smaller fault zones strongly diversify the interior of the SSW terrain and, furthermore, of second-order zones and blocks (Puura et al. 1983; Sildvee \& Vaher 1995). Unlike the NEGL, discordant anomalies are often restricted to the limits of local blocks, suggesting the development of the fault and block structure later than the formation of folded belts. Thus, in details, these areas consist of a great number of second- and third-order basement blocks, replaced relative to each other and coupled with specific magnetic and gravity anomalies. At the northeastern boundary of the Riga Pluton, annular anomalies of the anomaly field are superposed to the anomaly pattern usually characteristic of the folded granulite basement area. This is probably related to the rapakivi tectonics and intrusion in peripheries of the Riga Pluton (Puura et al. 1983). This area should be analysed and interpreted while modelling the structure of the Riga Pluton. Post- and anorogenic plutonic massifs are accompanied by nonlinear anomalies. Geophysical signatures of the latter show their discordant position in the linear fields of the metamorphic frame.

According to quantitative interpretations of gravity fields, the overthickened $(55-65 \mathrm{~km})$ crust in South Estonia produces huge gravity deficiency effects. However, in the expected negative regional gravity fields this area is expressed as a part of the BBGH. Our modelling revealed that the positive gravity effects of the 
dense granulitic upper crust and upthrusted blocks of the lower crust together hid the gravity low produced by the totally overthickened crust. Moreover, a mostly positive level of the gravity field has been registered here by field measurements. Thus, the described complex block and fault structure of the upper crust is coupled with the thickening of the lower crust on both interpretation profiles (Figs. 7 and 8). The granulite facies rocks, systematically exposed on the surface of the deeply eroded basement, suggest even much greater primary thickness of the crust than presently survived $55-65 \mathrm{~km}$. Recalculating the metamorphic pressure of 5-6 kbar into extra lithostatic pressure of around $15-20 \mathrm{~km}$, we should get the maximum total primary thickness of some $70-85 \mathrm{~km}$. Thus, it can be concluded that initially the upper crust had to be overthickened as well. Crustal shortening and thickening during the late orogenic compression, coupled with rapid erosion already during the orogen, could explain these estimations. Therefore, the high-grade rocks of South Estonia most probably inherit features of the late Svecofennian stacked sheets, as presumed by Gorbatschev \& Bogdanova (1993) and Puura \& Flodén (2000).

Previously, the West Estonian zone, with geophysical fields characteristic of the BBGH but with prevailing amphibolite facies of rock metamorphism, was somehow separated from the SSW terrain (Puura et al. 1983). According to recent interpretations by Koppelmaa (2002), granulite occurrences are here even more numerous than previously believed. However, certain specific features of this zone remain obvious. The prevailing density for the upper crust of the West Estonian zone is higher $\left(2750-2790 \mathrm{~kg} / \mathrm{m}^{3}\right)$ than for the regular Svecofennian crust within the NEGL, but clearly lower than for the South Estonian granulitic crust (2750$\left.2840 \mathrm{~kg} / \mathrm{m}^{3}\right)$. Southwestward from the MEF the dip of the borders of different blocks of the basement is nearly vertical or to the northeast, whereas in between the West Estonian, Tallinn, and Alutaguse zones the dip is commonly to the southwest. It suggests a specific field of compression in West Estonia. The modelling results show that the high level of the gravity field in West Estonia is mostly due to a greater amount of high-density component in the upper crust compared to the average Svecofennian crust, whereas the horizontal density distribution remains almost similar to that of the regular continental crust. Here the crust is of high density and less overthickened than elsewhere in the Estonian mainland, which is the main reason for the high level of gravity anomalies here.

\section{Transition between NNE and SSW terrains - the Paldiski-Pskov zone (PPZ)}

The main tectonic boundary in the Estonian basement, PPZ, has a transitional position between the Belarus-Baltic assemblage of prevailing granulitic terrains in the SSW and amphibolite facies zones in the NNE. The differences in the levels of magnetic and gravity anomalies of the BBGH and the NEGL have been attributed to differences in the densities and magnetic properties of rocks of the 
uppermost crust, which are both higher for granulites (Puura et al. 1983; Puura 1997). Two parallel NW-SE striking regional fault zones, with belt-form metamorphic blocks of the granulite or high-grade amphibolite facies in between, separate the two terrains. The opposite contact zones of the PPZ differ in geophysical and geological properties. In the NE, the transition is much more gradual in both geophysical and geological aspects. The composition of rocks and their metamorphic grade change rapidly from granulitic or high-grade amphibolitic in the PPZ to mainly medium-grade amphibolitic metasediments and intermediate to felsic metavolcanics, migmatites, and late-orogenic microcline granites in the Tallinn and Alutaguse zones. On the gravity map this structure is represented by a smooth gradient zone and on the map of magnetic anomalies by a step in the anomaly level. The latter is located southwestward from the northeastern limit of the gravity gradient zone. As can be deduced from the recent geological map (Koppelmaa 2002), so far no sharp geological boundaries have been detected in this transition zone.

The NE border of the PPZ is marked by a system of discordant negative magnetic and gravity anomalies suggesting the existence of a fault belt reworked by intrusive processes. Deep drillings revealed a zone of microcline granites and granite migmatites intruding metamorphic rocks of the granulite or amphibolite facies. The southwestern fault produces a linear negative magnetic anomaly associated with a flexure-like change on the gravity level. The flexure can be seen most clearly on the shaded relief maps (Figs. 5 and 6). Southwestward dipping granite and migmatite bodies penetrating to a depth of 5-15 km are interpreted in both profiles (Figs. 7 and 8). Core studies reveal that the tectonic lines along the PPZ represent deep zones of ductile deformation, at the SW border reworked by intrusions and veins of granites. The tectonic contact zones of the PPZ have not undergone cataclastic deformation and are therefore supposed to be of late orogenic origin.

\section{The post- to anorogenic Middle Estonian fault zone (MEF)}

The W-E striking MEF obliquely crosscuts the PPZ. The E-W striking MEF is well expressed as a linear belt of negative anomaly within the mainly high gravity and magnetic fields (Figs. 4-6). It divides the western part of the BBGH in Estonia into two portions and bisects the PPZ and Alutaguse zone in Central and East Estonia.

In its western part the MEF separates the different-grade parts of the granulite terrain - the proper granulite block in the south and the mainly amphibolite block, with spots of granulite, in the north (Fig. 1). A substantial vertical offset (south wall up) along this fault has been proposed (Puura et al. 1983; Koistinen et al. 1996; Puura \& Flodén 2000). In Central Estonia, the MEF crosscuts the PPZ and further to the east the southern part of the Alutaguse zone. Within or near this zone, post-orogenic granodiorite and quartz diorite massifs are located, pointing to the post-orogenic origin of the MEF. On the other hand, within the MEF the named 
intrusive bodies as well as the ordinary orogenic metamorphic and igneous rocks are subjected to intensive tectonic reworking. Cataclastites are found in many drill cores, suggesting brittle deformation in near-surface environments. These late cataclastic deformations possibly originate from block movements during the rapakivi-related tectonism and magmatism (Puura \& Flodén 2000).

\section{DISCUSSION AND CONCLUSIONS}

The geological study of the Estonian basement includes mainly petrography and bulk major-element chemistry of orogenic rocks (Puura et al. 1983; Koistinen et al. 1996; Koppelmaa 2002). Detailed investigations of metamorphism (Klein 1986; Hölttä \& Klein 1991; Kikas 2001) have been conducted in a few localities and are still in a very early stage. Tectonic environments and sources of magmatism have not been studied using modern petrological techniques based on minor element and isotope geochemistry and, thus, the tectonic settings of orogenic volcanism, plutonism, and sedimentation in Estonia are so far poorly understood.

Deformation tectonics of the orogenic basement has received much attention. Interpretation of geophysical data in complex with deep drillings and drill core studies have enabled effective mapping of the basement. The experience of the mapping has shown that pre-drilling prognosis of the basement composition is usually confirmed by the drilling results (Puura 1997).

As a result of the qualitative and semi-quantitative interpretation of potential field maps and drill core studies, essential dissimilarities between potential fields, structure, and rock assemblages of the basement in NNE Estonia on the one hand, and SSW Estonia and adjacent Baltic-Belarus region on the other hand, were determined already in the 1970s (Puura et al. 1976, 1983, 1984). At that time the Baltic-Belarus granulite-dominated basement was considered to be of Archaean age. However, Sm-Nd isotope studies of both Svecofennian orogenic belts in Finland (Huhma 1986) and the granulite area in South Estonia (Puura \& Huhma 1993) revealed the uniform Palaeoproterozoic isotopic age of the juvenile crust. It became obvious that the dissimilarities between these parts of the basement were due to differences in tectonic settings within the uniform Svecofennian crustal domain (Gorbatschev \& Bogdanova 1993). Results of the present study enabled quantification of the differences between the structural units of the Estonian basement.

Deep seismic sounding data and complex geophysical modelling show that in SSW Estonia the crust is substantially overthickened up to $55-65 \mathrm{~km}$. A great deal of the extra thickness is due to thickening of the lower crust. On the other hand, in the area of granulite facies the erosion was very deep. Furthermore, the present deep level of erosion was reached already before the time of rapakivi intrusion (Puura \& Flodén 2000). In this terrain, the composition of the metamorphic series is more mafic and dominated by volcanics. However, differences between deposition environments and sources of magmatism in the SSW and NNE parts of the 
mobile zone are still poorly studied. Tectonic stacking of crustal slices was the probable late orogenic Svecofennian process responsible for the main specific features of the basement in SW Estonia, including its thickness, vertical layering, and the extent of surface erosion. The assemblage of orogenic structures and rocks similar to that of SW Estonia is not largely developed in the exposed Svecofennian Domain of the Fennoscandian Shield.

The Tapa, Uljaste, and Jõhvi dome-like ore containing basement blocks of NNE Estonia (Puura et al. 1983; Klein 1986) are probably the analogues of granulite areas of South Finland (Koistinen 1994; Koistinen et al. 1996). The granulite terrain of SSW Estonia has a continuation in North Latvia and analogues in Lithuania and Belarus (Puura et al. 1976; Puura 1980). The concept of BalticBelarus arc-shaped granulite belts (Gorbatschev \& Bogdanova 1993) recently raised doubts again, because in Central Latvia, the Inchukalns $\mathrm{N}-\mathrm{S}$ trending amphibolite facies belt replaces the granulites of North Latvia, and in East Latvia, the large Daugavpils gneissose granite massif forms the basement (Puura 1980). Potential field maps point to a probable SSE continuation of the PPZ towards Belarus, but no deep core drillings have been performed to prove this possibility. Granulites more or less similar to those of the SSE area occur in the basement of Lithuania and Belarus. However, no recent comparative studies of these granulite or surrounding amphibolite facies structures are available and therefore the idea of the past Svecofennian mobile domain compressed and shortened from SSW to NNE (Nironen 1997) is still on the level of the principal model.

The Svecofennian Domain has a crust largely variable $(40-65 \mathrm{~km})$ in thickness (Korja 1995), belonging to the regions with the thickest crusts ever known on Earth (Durrheim \& Mooney 1994). The original orogenic variability of the crust has well survived in the domain except in the areas reworked by rapakivi igneous centres (Elo et al. 1993; Korja 1995; Puura \& Flodén 2000). Naturally, the thickness of the Earth's crust must have a marked influence on the regional gravity field. In NNE Estonia, in the amphibolite facies terrain the crust is moderately overthickened, and the regional field remains negative. Here, the Conrad level relief, together with the great amount of low-density matter in the upper crust, are the sources of these regional anomalies. In SSW Estonia, the negative gravity effect of the thick crust should be much stronger, but here it is compensated by the highdensity granulite facies blocks in the upper crust which, together with the uplifted blocks of the lower crust, give even positive anomalies. Therefore, reliefs of Moho and Conrad levels are important sources for long wavelength gravity anomalies and should be taken into consideration in choosing the level of the regional field for local gravity field maps. The sources for magnetic anomalies on the Estonian territory are mostly located in the upper crust.

The whole architecture of the basement of Estonia and southern Finland, together with the essential tectonic PPZ, may be interpreted as a result of compression and respective crustal shortening and thickening. The crustal shortening and thickening process was the most effective in WSW Estonia. Consequently, erosion was deeper in the area of the maximal thickening and highest past relief (SSW Estonia). The 
SW dip of the slices and faults within the PPZ and marginal parts of adjacent basement blocks, as deduced from the DSS data and supported by integrated modelling of magnetic and gravity data, is in agreement with the model of the crustal stacking. We suppose that the crustal thickening due to tectonic stacking is somehow responsible for the intracrustal melting and development of potassiumrich granites and migmatites in the metamorphic belts of Estonia and southern Finland. The southward continuation of this feature is not properly mapped yet.

The W-E striking MEF is a steep, nearly vertical fault zone, represented by cataclastic rocks in drill cores. It is interpreted as a postorogenic vertical fault zone displacing basement blocks for up to several kilometres. The MEF was reactivated during the anorogenic rapakivi magmatism. Consequently, the syn- and postrapakivi erosion of the block mountain area caused uneven erosion, superposed to the erosion surface worked out before the rapakivi-related tectonic activation.

\section{ACKNOWLEDGEMENTS}

We thank Dr. Heldur Sildvee for providing us with the digitized maps of Bouguer anomaly. Discussions with many geophysicists and geologists from the Geological Survey of Estonia and the Geological Survey of Finland were a valuable contribution to this research. We also thank the Geological Survey of Estonia for access to its extensive geophysical, petrophysical, and geological resources. The project was supported by the Geological Survey of Estonia and grants Nos. 2063, 2191, 4417, and 5817 of the Estonian Science Foundation. Financial support was also obtained from the Nordic Energy Petroleum Technology program as a personal scholarship for Tarmo All.

\section{REFERENCES}

All, T. \& Puura, V. 1998. Vertical extent of anorogenic rapakivi massifs in NW Estonia - interpretations of potential fields. Geofiz. Zh., 20, 54-57.

All, T., Gromov, O., Shuvalova, M. \& Eresko, E. 1999. Saaremaa piirkonna gravimeetrilise andmestiku revideerimine ja digitaliseerimine. Eesti Geoloogiakeskus, EGF 6350 (unpublished report, in Estonian).

All, T., Gromov, O., Shuvalova, M. \& Jeresko, J. 2002. Kesk-Eesti gravimeetrilise andmestiku revideerimine ja digitaliseerimine. Eesti Geoloogiakeskus, EGF 7456 (unpublished report, in Estonian).

Ankudinov, S., Sadov, A. \& Brio, H. 1994. Crustal structure of Baltic Countries on the basis of deep seismic sounding data. Proc. Estonian Acad. Sci. Geol., 43, 129-136.

Boiko, N. 1991. Otchet o rezul'tatakh aéromagnitnoj s"emki, provedennoj partiej aérogeofizicheskoj ékspeditsii 33 v 1988-1990 godakh na yuzhnom sklone Baltijskogo shchita po geologicheskomu zadanii 33/6-16-1. Nevskgeologiya, Leningrad, EGF 4576 (unpublished report, in Russian).

Durrheim, R. J. \& Mooney, W. D. 1994. Evolution of the Precambrian lithosphere: seismological and geochemical constraints. J. Geophys. Res., 99, 359-374. 
Elo, S., Lanne, E., Ruotoistenmäki, T. \& Sindre, A. 1989. Interpretation of gravity anomalies along the POLAR Profile in the northern Baltic Shield. Tectonophysics, 162, 135-150.

Elo, S. \& Korja, A. 1993. Geophysical interpretation of the crustal and upper mantel structure in the Wiborg rapakivi granite area, southeastern Finland. Precambrian Res., 64, $273-288$.

Faitelson, A. \& Aleksashin, V. 1968. Otchet o rabotakh Baltijskoj morskoj gravimetricheskoj partii No. 52/67 v Rizhskom zalive s obobshcheniem materialov po Pribaltike. Spetsgeofizika, Leningrad, EGF 3002 (unpublished report, in Russian).

Fotiadi, E. E. 1958. Geologicheskoe stroenie russkoj platformy po dannym regionaln'ykh geofizicheskikh issledovanij i opornogo bureniya. Gosgeoltehizdat, Moscow (in Russian).

Fursov, N. \& Ivanyukov, J. 1960. Otchet o rabotakh Pribaltijskoj aeromagnitnoj partii No 35/59 na territorii Latvijskoj i Éstonskoj SSR. Spetsgeofizika, Leningrad, EGF 1283 (unpublished report, in Russian).

Gorbatschev, R. \& Bogdanova, S. 1993. Frontiers in the Baltic Shield. Precambrian Res., 64, 3-21.

Henkel, H., Lee, M. \& Lund, C.-E. 1990. An integrated geophysical interpretation of the $2000 \mathrm{~km}$ FENNOLORA section of the Baltic Shield. In The European Geotraverse: Integrative Studies (Freeman, R., Giese, P. \& Müller, S., eds.), pp. 1-47. European Science Foundation, Strasbourg, France.

Hölttä, P. \& Klein, V. 1991. PT-development of granulite facies rocks in southern Estonia. Geol. Surv. Finland Spec. Pap., 12, 37-47.

Huhma, H. 1986. Sm-ND, U-Pb and Pb-Pb isotopic evidence for the origin of the Early Proterozoic Svecokarelian crust in Finland. Geol. Surv. Finland Bull., 337.

Kikas, R. 2001. Pressure-Temperature Evolution of High-Grade Svecofennian Gneisses near Saaremaa Shear Zone. MSc thesis, Institute of Geology, University of Tartu.

Klein, V. 1986. Metamorficheskij kompleks svekofenskogo pojasa v severnoj Éstonii. PhD thesis, Institute of Geology, Academy of Sciences of the Estonian SSR, Tallinn (unpublished, in Russian).

Koistinen, T. (ed.). 1994. Precambrian basement of the Gulf of Finland and surrounding area, Map $1: 1$ mill. Geological Survey of Finland, Espoo, 1 sheet.

Koistinen, T., Klein, V., Koppelmaa, H., Korsman, K., Lahtinen, R., Nironen, M., Puura, V., Saltykova, T., Tikhomirov, S. \& Yanovskiy, A. 1996. Paleoproterozoic Svecofennian orogenic belt in the surroundings of the Gulf of Finland. In Explanation to the Map of Precambrian Basement of the Gulf of Finland and surrounding area 1:1 million (Koistinen, T., ed.). Geol. Surv. Finland Spec. Pap., 21, 21-57.

Koppelmaa, H. 2002. Geological Map of the Crystalline Basement of Estonia. Scale 1:400 000. Explanation to the Map. Geological Survey of Estonia, Tallinn.

Koppelmaa, H. \& Kivisilla, J. 2000. Geological Map of the Crystalline Basement of Northern Estonia. Scale 1:400 000. Explanation to the Map. Geological Survey of Estonia, Tallinn.

Korhonen, J., Säävuori, H. \& Kivekäs, L. 1997. Petrophysics in the Crustal Model Program of Finland. Geol. Surv. Finland Spec. Pap., 23, 157-173.

Korhonen, J., Koistinen, T., Elo, S., Säävuori, H., Kääriäinen, J., Nevanlinna, H., Aaro, S., Haller, L. Å., Skilbrei, J. R., Solheim, D., Chepik, A. K., Zhdanova, L., Vaher, R., All, T. \& Sildvee, H. 1999. Preliminary magnetic and gravity anomaly maps of the Fennoscandian shield $1: 10000$ 000. Geol. Surv. Finland Spec. Pap., 27, 173-179.

Korja, A. 1995. Structure of the Fennoscandian Crust - Growth and Destruction of the Svecofennian Orogen. Institute of Seismology, University of Helsinki, Report S-31.

Lahtinen, R. \& Korhonen, J. 1996. Comparison of petrophysical and rock geochemical data in the Tampere-Hämeenlinna area, southern Finland. Geol. Surv. Finland Bull., 392.

Lapina, J. \& Samoilyuk, V. 1966. Otchet o aéromagnitnoj s"emke masshtaba 1:50 000, provedennoj v 1965 g. na territorii yuzhnogo sklona Baltijskogo shchita i v predelakh Belorusskogo kristallicheskogo massiva. Spetsgeofizika, Leningrad, EGF 2565 (unpublished report, in Russian). 
Luosto, U. 1991. Moho Depth Map of Fennoscandian Shield Based on Seismic Refraction Data. Institute of Seismology, University of Helsinki, Report S-25, 43-50.

Maasik, V. 1959. Gravitatsionnoe pole na territorii Éstonskoj SSR i ego primenenie. Institute of Geology, Academy of Sciences of the Estonian SSR, Tallinn, EGF 1392 (unpublished report, in Russian).

Margot, M. 1997. Normaalvälja valemite analüüs, Balti kõrguste süsteemi ja gravimeetrilise geoidi vahe arvutamine ning Eesti GPS gravimeetrilise geoidi kaardi koostamine. Estonian Agricultural University, Land Surveying, Tartu (unpublished diploma project, in Estonian).

Marker, M., Henkel, H. \& Lee, M. 1990. Combined gravity and magnetic modelling of the Tanleva and Lapland Granulite Belt, Polar profile. In The European Geotraverse: Integrative Studies (Freeman, R., Giese, P. \& Müller, S., eds.), pp. 67-76. European Science Foundation, Strasbourg, France.

Metlitskaya, V. \& Popko, A. 1992. Otchet o rezul'tatakh aéromagnitnoj s"emki masshtabov $1: 25000,1: 50000$ na territorii Éstonii i prilegayushchego shelfa, provedennoj partiej No. 49 v 1987-1991 gg. PO Belorusgeologiya, Minsk, EGF 4629 (unpublished report, in Russian).

Nironen, M. 1997. The Svecofennian orogen: tectonic model. Precambrian Res., 86, 21-44.

Ostrovski, A. 1990. Seismic investigations in the Baltic Sea (23rd cruise of R/V "Professor Shtokman", July 3-September 1, 1989). Oceanology, 30, 512-513.

Pesonen, L. J., Torsvik, T. H., Elming, S. A. \& Bylund, G. 1989. Crustal evolution of Fennoscandia - paleomagnetic constraints. Tectonophysics, 162, 27-49.

Puranen, R. 1989. Susceptibilities, Iron and Magnetite Content of Precambrian Rocks in Finland. Geological Survey of Finland, Report of Investigation, 90.

Puura, V. (ed.). 1980. Geological map of the crystalline basement of the East Baltic. Scale $1: 1000$ 000. VSEGEI, Leningrad, 1 sheet.

Puura, V. 1997. Petrophysics as a tool of subsurface mapping of the crystalline basement in the Baltic region. In Petrophysics in Potential Field Interpretation. First Workshop for the Finnish Geophysical Crustal Model Program 15-16 August 1997, Espoo, Finland (Korhonen, J., ed.), pp. 41-42. Geological Survey of Finland, Espoo, Finland.

Puura, V. \& Flodén, T. 1999. Rapakivi-granite-anorthosite magmatism - a way of thinning and stabilisation of the Svecofennian crust, Baltic Sea Basin. Tectonophysics, 305, 75-92.

Puura, V. \& Flodén, T. 2000. Rapakivi-related basement structures in the Baltic Sea area, a regional approach. GFF, 122, 252-272.

Puura, V. \& Huhma, H. 1993. Palaeoproterozoic age of the East Baltic granulite crust. Precambrian Res., 64, 289-294.

Puura, V., Kuuspalu, G., Birkis, A., Vasiljev, V., Gailius, R., Koppelmaa, H. \& Niin, M. 1976. General geology of the basement of the East Baltic region. In Geologiya, petrologiya $i$ metallogeniya kristallicheskikh obrazovanij Vostochno-Evropejskoj platformy, pp. 40-48. Nedra, Moscow (in Russian).

Puura, V., Vaher, R., Klein, V., Koppelmaa, H., Niin, M., Vanamb, V. \& Kirs, J. 1983. The Crystalline Basement of Estonian Territory. Nauka, Moscow (in Russian, with extended English summary).

Puura, V., Birkis, A. \& Motuza, G. 1984. Tectonics of the crystalline basement of the East Baltic region. In Tektonicheskie issledovaniya zapada Vostochno-Evropejskoj platformy (Garetskij, R., ed.), pp. 43-55. Nauka i tekhnika, Minsk (in Russian).

Puura, V., Amantov, A., Koistinen, T. \& Laitakari, I. 1992. The Precambrian basement. In Geologiya Finskogo zaliva (Raukas, A. \& Hyvärinen, H., eds.), pp. 13-29. Estonian Academy of Sciences, Tallinn (in Russian).

Sildvee, H. 1997. Raskuskiirenduse mõõdistamised ja gravimeetrilised kaardid Eestis. Geodeet, 13, 9-12.

Sildvee, H. \& Vaher, R. 1995. Geologic structure and seismicity of Estonia. Proc. Estonian Acad. Sci. Geol., 44, 15-25. 
Soesoo, A., Puura, V., Kirs, J., Petersell, V., Niin, M. \& All, T. 2004. Outlines of the Precambrian basement of Estonia. Proc. Estonian Acad. Sci. Geol., 53, 149-164.

Stepanov, I., Boiko, N., Smirnov, A. \& Neratov, M. 1992. Otchet o rezul'tatakh aéromagnitnoj s"emki, provedennoj partiej 6 RGÉTS v 1991 godu v Tsentral'noj i Yugo-vostochnoj Éstonii po dogovoru s Éstonskim Geologicheskim Tsentrom. Nevskgeologiya, SanktPeterburg, EGF 4576 (unpublished report, in Russian).

Suuroja, S., All, T., Plado, J. \& Suuroja, K. 2002, Geology and magnetic signatures of Neugrund Impact Structure, Estonia. In Impacts in Precambrian Shields (Plado, J. \& Pesonen, L., eds.), pp. 277-295. Springer Verlag, Heidelberg.

\title{
Eesti aluskorra orogeenne struktuur kompleksse magnetvälja ja raskusjõuvälja modelleerimise andmetel
}

\author{
Tarmo All, Väino Puura ja Rein Vaher
}

Paleoproterosoilise (1,9-1,8 Ga) Svekofennia aluskorra orogeense struktuuri modelleerimise aluseks võeti uusimad raskusjõu ning magnetiliste anomaaliate kaardid ja süvaseismilise profileerimise andmed. Kolmemõõtmeline modelleerimine viidi läbi kahel põhja-lõunasuunalisel profiilil. Kogu maakoor jagati modelleerimise käigus homogeense ehitusega kurrutatud kivimite plokkideks ja neid eraldavateks murranguvöötmeteks. Aluskorra kivimite koostise, tekketingimuste ja füüsikaliste omaduste iseloomustamisel toetuti eelkõige puursüdamike andmetele, mida täiendati geofüüsikaliste uuringute materjalidega. Svekofennia koor koosneb valdavalt moondekivimitest ja on ümbritsevate aluskorrasegmentide taustal ülepaksenenud. Selline koor eeldab ulatuslikku regionaalset raskusjõumiinimumi, mis on aga vastuolus teadaoleva ülakoore kivimilise koostise ning Bougueri anomaaliate jaotumusega.

Modelleerimistulemused näitasid, et raskusjõu ja magnetvälja regionaalne muutlikkus on seotud lateraalsete ja plokiliste erinevustega kogu maakoore ulatuses. Kui Põhja- ja Kirde-Eestis leviv paks ja kerge ülakoor kutsub esile regionaalse miinimumi, siis Lõuna-Eestile omane paks ja tihe ülakoor ja ülepaksenenud tihe alakoor põhjustavad positiivseid raskusjõu anomaaliaid, millega assotsieeruvad valdavalt positiivsed magnetvälja väärtused. Eesti aluskorda poolitav loode-kagusuunaline Paldiski-Pihkva hõõrdevööde on kallutatud edelasse ning kujunenud hilis-Svekofennia kompressiooniperioodil, lääne-idasuunaline Kesk-Eesti püstmurrang aga rabakiviaegsete tektooniliste liikumiste tulemusel. 